4. Лазнева I. О., Цараненко Д. І. Кіберспорт та його вплив на зміну структури світового ринку комп'ютерних ігор. Науковий вісник Ужгородського національного університету. Випуск 22, частина 2. 2018. С. 3-67

5. Лисенко Т., Морозова О. Ознаки кіберспорту як спортивної дисципліни. Науково-методичні основи використання інформаційних технологій в галузі фізичної культури та спорту : збірник наукових пращь. Харків : ХДАФК, 2019. Випуск 3. С. 63-67.

6. Про затвердження Реєстру визнаних видів спорту в Україні Наказ Міністерства молоді та спорту України (№ 639 від 11.03.2015). URL: https://zakon.rada.gov.ua/rada/show/v0639728-15. (дата звернення: 12.08.2019).

7. Чайка Є.В. Стан та динаміка росту ринку кіберспорту. Економічний вісник Національного технічного університету України «Київський політехнічний інститут». 2018. № 15. C. 443-452.

8. Cunningham B.. Why eSports Is The Next Big Thing In Marketing? URL: https://www.forbes.com/sites/baldwincunningham/2016/02/25/why-esports-is-the-next-bigthing-in-marketing/. (дата звернення: 10.08.2019).

9. Global Game Market Report (Free version). NewZoo. 2019. URL: https://newzoo.com/insights/trend-reports/newzoo-global-esports-market-report-2019-lightversion/. (дата звернення: 10.08.2019).

10. Greenfield P.M. The Cultural Evolution of IQ. The Rising Curve. Long-TermGainsin IQ and related Measures. Washington. 1998. P. 81-123.

11. Hunter S. Digital Natives: The Rise of Esport. URL: https://www.parksassociates.com/bento/shop/samples/Parks\%20Assoc\%20Digital\%20Natives\% 20Rise\%20of\%20Esports\%20TOC.pdf. (дата звернення: 08.08.2019).

12. Wiseman L. The future of esports marketing. URL: https://venturebeat.com/2017/11/09/the-future-of-esports-marketing-2/. (дата звернення: 08.08.2019).

\title{
МАРКЕТИНГОВИЙ РОЗПОДІЛ ІННОВАЦЙНОЇ ПРОДУКЦІї ВИСОКОТЕХНОЛОГІЧНИХ ПІДПРИЕМСТВ НА ОСНОВІ ВІРТУАЛЬНОГО ЗАБЕЗПЕЧЕННЯ ТА ЕКОЛОГІСТИКИ
}

\section{THE MARKETING DISTRIBUTION OF HIGH-TECH ENTERPRISES INNOVATIVE PRODUCTS OF BASED ON VIRTUAL PROVIDING AND ECOLOGISTICS}

Стаття присвячена уточненню і поглибленню розуміння сутності інтеграційної взаємодії маркетингу $і$ логістики в концепційній системі маркетингового просування інноваційної продукції з урахуванням зелених $i$ віртуальних інформаційних аспектів формування логістичної системи високотехнологічних підприємств України. Удосконалено маркетингову ичіннісну процедуру поліканального розподілу інноваційної продукиіі високотехнологічних підприємств на основі віртуального забезпечення екологістики. Комплексне застосування концепиії екологістики дозволяє досягти всеосяжного забезпечення комфортної, чистої $i$ безпечної взаємодії із навколишнім 
середовищем упродовж усього маркетингового ланщюга. Унаслідок застосування маркетингової ичіннісної процедури поліканального розподілу інноваційної продукиії високотехнологічних підприємств на основі віртуального забезпечення екологістики відбувається досягнення зрівноваженого маркетингового ланщюга створення потоків додаткової маркетингової вартості у межах концепиії зеленої логістики. Водночас має відбуватися збільшення потоків маркетингової цінності у межах регіонального ланцюга поставок. Проведено аналіз комплексного застосування Інтернет-технологій високотехнологічних підприємств Украӥни та їх відповідну структуру. Встановлено, щэо найбільшу питому вагу в загальному використанні мережі Інтернет високотехнологічними підприємствами Украӥни протягом 2017-2018 рр. посідають такі напрямки, як: надсилання чи отримання повідомлень електронною поштою та отримання інформації про товари та послуги. Виявлені аналітичні тенденції засвідчують комплексне збільшення площини і масштабів використання Інтернет-маркетингових комунікацій за усіма напрямками технологічної бізнес-взаємодії високотехнологічних підприємств України. Тому маркетологи $i$ логісти мають системно проводити моніторинг комунікаиійної активності підприємств за комплексом логістичнокомунікаційних напрямків. Це сприятиме підвищенню інтенсивності ци вартісній наповненості потоків маркетингових цүінностей, щэо спрямовуються до цілььових груп споживачів.

Ключові слова: маркетинговий розподіл, інноваційна продукція, віртуальні технології, концепція екологістики, иүінність.

The article is devoted to clarifying and deepening the understanding of the essence of integration interaction between marketing and logistics in the concept system of innovative products marketing promotion. Green and virtual information aspects of the Ukraine high-tech enterprises logistics system formation described. The marketing value procedure of multichannel distribution of high-tech enterprises innovative products on the basis of virtual support of logistic green concept has been improved. Comprehensive application of the logistic green concept allows to achieve comprehensive provision of comfortable, clean and safe interaction with the environment throughout the marketing chain. As a result of the application of the marketing value procedure of high-tech enterprises innovative products multi-channel distribution on the basis of virtual support of logistic green concept, a balanced marketing chain of creation of additional marketing value flows within the framework of the green logistics concept is achieved. At the same time, marketing value flows within the regional supply chain should increase. An analysis of the integrated application of Internet technologies of high-tech enterprises of Ukraine and their corresponding structure was carried out. It has been established that the largest share in the general use of the Internet by Ukraine high-tech enterprises during 2017-2018 is occupied by such areas as: sending or receiving e-mail messages and receiving information about goods and services. The detected analytical trends certify the complex increase in the plane and scale of use of Internet marketing communications in all directions of technological business interaction of Ukraine high-tech enterprises. Therefore, marketers and logists should systematically monitor the communication activity of enterprises in a complex of logistics and communication directions. This will increase the intensity and marketing value streams that are directed to target consumer groups.

Keywords: marketing distribution, innovative products, virtual technologies, logistic green concept, value.

Вступ. Інноваційний розвиток світових i регіональних процесів маркетингової бізнес-взаємодії привертає увагу дослідників до висвітлення комунікаційного i логістичного забезпечення ринкових транзакцій 3 урахуванням позицій і інтересів цільових споживачів, громадськості, влади, 
бізнесу та стейкхолдерів. Стрімке інформаційне наповнення супроводження трансрегіональних маркетингових операцій високотехнологічних підприємств (ВТП) висуває системні вимоги до оновлення принципів, методів, процедур та моделей організації та координування Інтернетмаркетингових комунікацій та е-логістики. У глобальному віртуальному середовищі особливого значення набуває інтеграційна діяльність віртуальних логістичних операторів класу 5PL.

Дослідженням низки нагальних світових i регіональних проблем організації інноваційного маркетингу і менеджменту, логістики рециклінгу, визначення зелених аспектів формування логістичних систем ВТП, маркетингового ціноутворення в умовах цифрової бізнес-взаємодії присвячені праці вітчизняних i закордонних учених-маркетологів, економістів таких як: І. Білик [11], М. Васелевський [11], Майа Голованова [10], О. Дейнега [11], С. М. Ілляшенко [5], Є. В. Крикавський [11], А. А. Мазаракі [1], Юстина Майхжак-Лепчик [2], Анна Мариняк [2], Л. Г. Харсун [1] та інші. Теоретико-методичну сутність застосування маркетингових стратегій збуту в кіберсередовищі на високотехнологічних ринках; комплекс Інтернет інструментів організації i координування маркетингу авіаційної галузі висвітлено у наукових працях таких вчених, як: Є. А. Домашева [8], О. В. Зозульов [8], С. О. Лебеденко [7], Н. К. Мороз [7].

Проте потребує науково-методичного висвітлення низка питань, пов'язаних iз ефективним логістичним менеджментом у площині інтегрованого функціонування зелених логістичних ланцюгів, коли генерування значних потоків маркетингових цінностей підкріплюється відповідним комунікаційним та віртуальним інформаційним забезпеченням.

Постановка завдання. Метою цієї статті є удосконалення теоретикометодичних засад маркетингового розподілу продукції високотехнологічних підприємств на основі інтеграційного віртуального забезпечення та екологістики, спрямоване на стійкий розвиток та підвищення потоків маркетингових цінностей.

Відповідно до мети у даній роботі поставлені такі завдання:

- уточнити i поглибити розуміння сутності інтеграційної взаємодії маркетингу і логістики в концепційній системі маркетингового просування інноваційної продукції з урахуванням зелених і віртуальних інформаційних аспектів формування логістичної системи високотехнологічних підприємств України;

- удосконалити маркетингову ціннісну процедуру поліканального розподілу інноваційної продукції високотехнологічних підприємств на основі віртуального забезпечення екологістики;

- проаналізувати комплексне застосування Інтернет-технологій високотехнологічних підприємств України та їх відповідну структуру.

Відповідно до сформульованих завдань об'єктом дослідження у даній роботі $\epsilon$ процес маркетингового розподілу продукції високотехнологічних підприємств в темпоральному інформаційно-комунікаційному середовищі. 
Предметом дослідження $є$ теоретико-методичні аспекти та методологічні положення маркетингового розподілу інноваційної продукції ВТП на основі віртуального забезпечення та екологістики.

Методологія. Методологічною базою проведеного дослідження $\epsilon$ діалектичний метод пізнання та системний підхід, структурно-логічний аналіз, історичний та логічний підходи, концепція маркетингового розподілу, графічний метод, теорії маркетингу, інновацій, конкуренції, маркетингової та комунікаційної ефективності.

Результати дослідження. Комплексу значущих науково-практичних положень у сфері інтеграції інноваційного маркетингу та екологістики ВТП присвячено праці науковців і практиків. Так, А. А. Мазаракі, Л. Г. Харсун (A. A. Mazaraki, L. G. Kharsun) досліджують комплекс зелених аспектів формування логістичної системи України, наголошуючи про доцільність встановлення відповідності атрибутів створення доданої вартості в межах логістичного ланцюга міжнародним екологічним вимогам. Формування екологістики у межах екологічної концепції логістичної діяльності високотехнологічних підприємств має відбуватися з урахуванням високого рівня екологічної свідомості сучасних освічених споживачів, економічних і соціальних агентів, влади і громадськості [1, с. 4].

Науковці наголошують про переважання транснаціональних ланцюгів постачання, які можуть бути організовані на засадах дотримання суцільної екологічності багатьох логістичних процедурі процесів. Слушно зазначається про необхідність досягнення відповідності логістичного середовища України екологічним вимогам і стандартам $Є С$ [1, с. 4]. Дослідники моделюють низку екологічних проблем, що часто постають перед бізнес-структурами i зумовлені організацією логістичної діяльності. Окреслюються значні потоки емісії пилу i газу під час переміщення ресурсних потоків у межах логістичного ланцюга. Також слід визначати ступінь шумового, пилового i електромагнітного забруднення довкілля. Важливою $є$ агрегація виробничих відходів, відходів пакувальних матеріалів. Слід відслідковувати безпечне 3 екологічної точки зору споживання енергетичних та інших природних ресурсів, у контексті можливої зміни природного ландшафту [1, с. 4-5]. На наш погляд, всеосяжне забезпечення комфортної, чистої і безпечної взаємодії iз навколишнім середовищем упродовж усього маркетингового ланцюга може створювати вагомі інноваційні конкурентні переваги сучасним ВТП на міжнародних і регіональних ринках високотехнологічної продукції і послуг.

Юстина Майхжак-Лепчик, Анна Мариняк (Justyna Majchrzak-Lepczyk, Anna Maryniak) досліджують формування попиту на складську поверхню в країнах $\mathrm{CC}$, зокрема у Польщі, наголошуючи на значному зрості складських поверхонь у Польщі, які за роки членства в СС змінилися з 1 млн м² у 2004 р. до 8,5 млн м² у 2014 р. [2, с. 26]. Зазначається, що у часі вступу до СС у 2004 р. Польща мала 631 км автомобільних доріг із прискореним рухом і автострад. Уже у 2014 р. у цій країні було сформовано до використання у логістичних цілях 3000 км доріг із прискореним рухом, 1553,3 км автострад, 
1467,5 експресних доріг [2, с. 26]. Таке розширення дорожньої інфраструктури спонукало до зростання обсягів складування, спричиняючи до певного перенесення логістичної діяльності виробників і дистрибуторів 3 інших країн до Польщі. При цьому інтенсивно будуються нові складські приміщення, експедиційні, транспортні термінали і логістичні дистрибуційні центри [2, с. 26]. Ми гадаємо, що слід ураховувати «добрі» логістичні маркетингові практики польських компаній, які постійно у часі і просторі піклуються про дотримання вимог екологічної безпеки упродовж маркетингового ланцюга генерування доданої вартості [3].

O. В. Зозульов (O. V. Zozuliov) висвітлює змістовні елементи концепції організації бізнесу, встановлюючи методичні складові взаємозумовленості ефективної стратегії маркетингу та стратегії взаємозумовленості бізнесу. Він виокремлює філософську, управлінську, організаційну, функціональну, сутнісну, ціннісну, процесну та інституціональну трактовки концепції маркетингу, наголошуючи на іiі спрямування щодо збільшення потоку цінностей та забезпечення високої ефективності управління капіталом $[4$, c. 65]. Науковець комплексно аналізує застосування таких стратегічних моделей управління маркетингом та організації бізнесу, як: корпоративна модель організації бізнесу на основі ланцюга створення вартості М. Портера, мережева модель організації бізнесу на основі синергетичного створення цінності, мережева модель організації бізнесу на основі закритих екосистем.

При цьому наголошується на значущості окреслення ключового бізнеспроцесу чи функції, що генерує потоки маркетингових цінностей у випадку першої корпоративної моделі. Слушно акцентується на досягнення системної мережевої інтеграції з багатьма ринковими агентами, коли використовуються конкурентні переваги за межами фірми у площині якірних підприємствпартнерів. Дослідник висвітлює функціонування мережевої моделі організації бізнесу на основі закритих екосистем, що базується на системно інтегрованій екосистемі, що комплексно узгоджує постачання і споживання [4, с. 66-71]. На наш погляд, означені стратегічні моделі відображають світову тенденцію до інтеграції маркетингу і логістики у площині організації інноваційних бізнес-процесів, що здатні генерувати суттєві конкурентні переваги економічних агентам у глобальному і регіональному вимірі. У такій інтеграції суттєве місце посідає застосування концепцій екологічного, соціально-відповідального маркетингу, концепції маркетингу 3.0. При цьому увагу науковців і практиків у сфері маркетингу і логістики усе більше привертають питання функціонування зрівноваженого маркетингового ланцюга створення потоків додаткової маркетингової вартості, концепція зеленої логістики.

C. M. Ілляшенко (S. M. Iliashenko) досліджує маркетинг і логістику в концепційній системі маркетингового просування інноваційної продукції на регіональні ринки України, наголошуючи на їх певному розробленні i запровадженні при виконанні держбюджетної теми «Розроблення механізму комерціалізації інноваційної продукції», № ДР 0118U003572. Справедливо 
зазначається про доцільність визначення маркетингового та логістичного забезпечення функціонування регіональних ринків, що, за інших рівних умов, на основі пришвидшення інтеграційної взаємодії, зокрема на ринку інновацій, сприятиме зростанню рівня конкурентоспроможності підприємств, регіонів та країни $[5$, с. 176]. Науковець слушно визначає поняття «Логістичний потенціал регіону», що віддзеркалює накопичення елементів i чинників логістичної інфраструктури, які забезпечують формування та розподілення комплексу ресурсних потоків. Позитивним моментом дослідження $\epsilon$ диференційоване визначення складової структури логістичного потенціалу регіонів за комплексом таких складових, як: транспортний, кадровий, споживчо-збутовий, сервісний, просторовий та транзитний [5, с. 178-179].

Дослідник при цьому пропонує матрицю групування регіонів України за рівнями оцінки маркетингового забезпечення та логістичного потенціалу, що відображає територіальне групування регіонів України за семи зонами. Встановлено нестійкість у формуванні логістичного потенціалу у межах Івано-Франківської, Тернопільської та Київської областей. Така оцінка і діагностика дозволяє встановити низку ризиків при розподілення товарних i сервісних потоків у регіонах. Окреслюється логістичний статус території 3 урахуванням певного масштабування, вибудовуються науково-методичні підходи до збільшення маркетингової цінності у межах регіонального ланцюга поставок, що дає змогу досягати високої якості логістичного сервісу [5, с. 182]. Ми вважаємо, що маркетингове логістичне забезпечення, як i логістичний потенціал територій у глобальному і регіональному масштабах мають отримувати своє накопичення у віртуальному інформаційному середовищі. У цьому середовищі мають активно формуватися схеми i процедури організації електронного бізнесу у високотехнологічній сфері маркетингової бізнес-взаємодії [6, с. 182-186].

С. О. Лебеденко, Н. К. Мороз (S. O. Lebedenko, N. K. Moroz) досліджують комплекс Інтернет інструментів організації і координування маркетингу авіаційної галузі, зокрема державного підприємства «Антонов». Визначається, що Інтернет-маркетинг у площині успішної організації електронної авіаційної комерції має на синергічних засадах поєднувати такі елементи, як: Інтернет-інтеграція, інформаційний менеджмент, зв'язки 3 громадськістю, служба роботи 3 покупцями i продажу [7]. Науковці описують переваги і недоліки SMM - просування в соціальних мережах через сторінки бренду / компанії, що може бути застосовано у цифровому авіаційному маркетингу. Креативне наповнення мають потоки повідомлень 3 таргетингової реклами, які влучно можуть потрапляти до певних груп цільової аудиторії. Також аналізується застосування E-mail маркетингу, контент-маркетингу, що завдяки публікуванню інформації у блогах засвідчує експертність та підвищує прихильність споживачів до бренду. Дослідники оцінюють застосування нативних рекламних форматів та комунікаційної взаємодії у месенджерах [7]. 
Ми гадаємо, що погляди науковців характеризуються певним узагальненим застосуванням цифрових маркетингових технологій, слід розширити наведені специфічні риси організації Інтернет-маркетингу для такого ВТП, як ДП «Антонов». Щодо кожного із елементів Інтернетмаркетингового комунікаційного просування варто розробляти аналітичні процедури, методи, моделі і технології, що якнайповніше будуть доносити до середовища економічних і соціальних агентів специфіку маркетингового позиціонування і логістичного сервісу інноваційної продукції авіабудування.

Зауважимо, що у контексті побудови логістичних систем у Центральній та Східній Європі у другій декаді XXI століття доцільно розвивати логістичне партнерство регіонів між Україною і Польщею. Сучасні економічні і соціальні агенти повинні оперативно реагувати на виклики i перспективи розвитку соціально-економічної та міжнародної ситуації у Східній Європі у XXI столітті. У цьому контексті варто відмітити науковоінтеграційну діяльність Комісії 3 досліджень Європейської інтеграції Польської Академії Наук та іï регіональних представництв. При цьому у рамках розвитку співпраці між наукою, освітою, владою, бізнесом, суспільством доцільно визначати місце польської громади в Україні та української громади у Польщі у процесах поглиблення маркетингової логістичної співпраці між партнерськими регіонами двох країн. Відмітимо, що економічно-соціологічний факультет, Міжнародний центр СхідноСвропейських досліджень (International Centre for East European Research / Międzynarodowe Centrum Badań Wschodnioeuropejskich) Лодзьського університету (University of Lodz) [8] здійснюють комплексний аналіз економічних проблем i питань, що стосуються реалізації європейської економічної інтеграції України та польсько-української логістичної співпраці на міжнародній арені.

Є. А. Домашева, О. В. Зозульов (Е. A. Domasheva, O. V. Zozuliov) досліджують сутність застосування маркетингових стратегій збуту в кіберсередовищі на високотехнологічних ринках, наголошуючи на значущості у сьогоднішньому гіпердинамічному ринково-інформаційному просторі оптимальної організації електронного збуту. Вони комплексно наводять такі головні відмінності маркетингу в кіберсередовищі, як: розширення маркетингової бази даних, підвищення ступеня прозорості та симетричності інформаційного забезпечення під час прийняття рішення, усесвітне блискавичне розповсюдження інформаційних потоків, інтеграція множинних каналів збуту, чітке і релевантне наповнення маркетингових комунікаційних повідомлень [9, с. 300-301].

Особливістю запропонованої схеми збуту підприємства у кіберсередовищі $є$ застосування інформаційних посередників (інтегратори, агрегатори, консолідатори) у крос, мульти, омніканальному збуті [9, с. 303]. Науковці за критеріями типу залученого середовища, ступеня утримання клієнта, суб'єкту реалізації дій, маркетингові рішення для власних і зовнішніх ресурсів виокремлюють систему маркетингових стратегій збуту в 
кіберсередовищі. Типологія таких стратегій диференціюється у такій ринково обгрунтованій послідовності, як: онлайнові, змішані; одноканальний, мультиканальний, крос-канальний, омніканальний збут, комерційна релевантність; самостійний збут, використання інформаційних посередників, IaaS, PaaS, SaaS, XaaS; інтегратори, агрегатори, консолідатори [9, с. 304-305].

Заслуговує на увагу виокремлення науковцями певних детермінант визначення стратегій збуту в кіберпросторі, а саме: у кількісному вимірі вартість фінансових потоків, ціна одного ліду, швидкість вступу на ринок, прогноз потоку виторгу від реалізації. Серед якісних детермінант стратегій збуту дослідники виокремлюють такі, як: IT-компетенція, розташування груп цільової аудиторії, особливості продукції, життєвий цикл підприємства [9, с. 306]. Ми вважаємо, що функціонування поліканальних збутових систем і мереж повинне мати відповідне віртуальне інформаційне відображення і забезпечення, що створює об'єктивні можливості для нарощування вартості потоків маркетингових цінностей, спрямовуваних до цільових сегментів.

Представник наукової школи економіки та маркетингу Національного аерокосмічного університету ім. М. С. Жуковського «Харківський авіаційний інститут» Майа Голованова (Maja Golovanova) досліджує специфіку динамічного ціноутворення, наголошуючи на застосуванні сучасних методів управління прибутком на базі моніторування та аналізу зміни цін. Підкреслюється про доцільність застосування у ході динамічного ціноутворення просторової і часової цінової дисперсії з використанням ITпродуктів та комп'ютерного моделювання. Зокрема, таке цінове налаштування може стосуватися визначення цін (тарифів) на маршрути авіаперельотів [10, с. 18]. Вона зазначає про ефективність управління доходами компаній на базі відповідного інформаційного забезпечення, що дозволяє аналізувати успішність поточних продажів у порівнянні зі змістом і структурою наявного і потенційного попиту [10, с. 18-20]. Ми вважаємо, що слід розвивати методичні підходи до маркетингового ціноутворення в мережі Інтернет, ураховуючи значущість цифрового забезпечення під час організації маркетингового розподілу продукції.

3 урахуванням висвітленої наукової дискусії та тенденцій розвитку маркетингового розподілу в контексті системного інтегрування маркетингу та екологістики пропонуємо маркетингову ціннісну процедуру поліканального розподілу інноваційної продукції ВТП на основі віртуального забезпечення екологістики (рисунок). 


\section{1. Зелені аспекти формування логістичної системи ВТП. Формування екологістики: всеосяжне забезпечення комфортної, чистої і безпечної взаємодії із навколишнім середовищем упродовж усього}

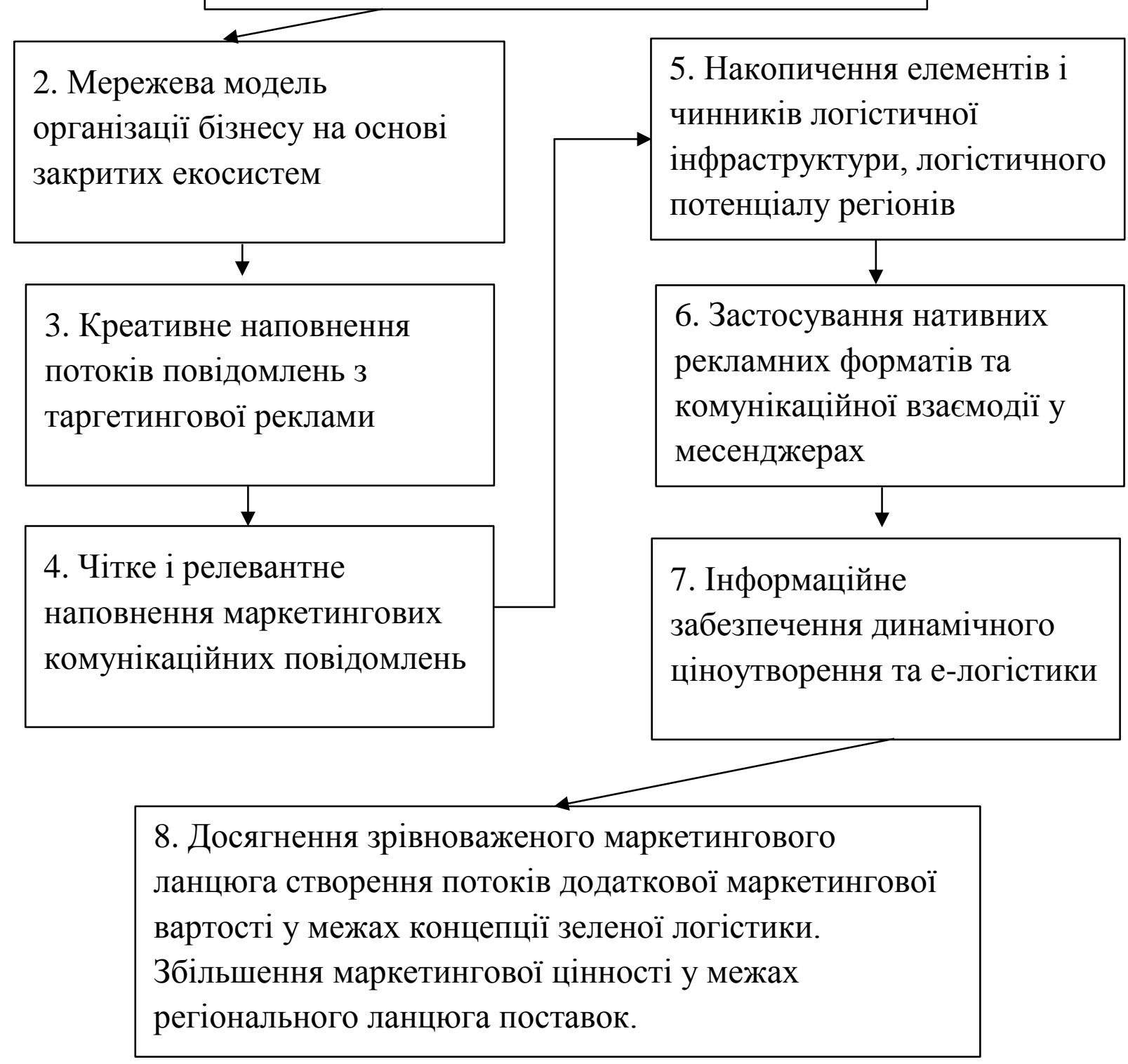

Рисунок - Маркетингова ціннісна процедура поліканального розподілу інноваційної продукції ВТП на основі віртуального забезпечення екологістики

Джерело: удосконалено автором на основі [1, с. 4-5; 4, с. 65-71; 5, с. 178-182; 7; 9, c. $300-303 ; 10$, c. $18-20]$

Як свідчить взаємодія процедурних блоків у процесі формування необхідних маркетингових ціннісних потоків для цільових груп ринкових агентів, доцільно відразу з'ясувати зелені аспекти формування логістичної системи ВТП, що сприятиме формуванню дієвої концепції екологістики. 
Комплексне застосування такої концепції дозволяє досягти всеосяжного забезпечення комфортної, чистої і безпечної взаємодії із навколишнім середовищем упродовж усього маркетингового ланцюга (блок 1). У часовопросторовій площині блоку 2 формується мережева модель організації бізнесу на основі закритих екосистем. При цьому креативне наповнення потоків повідомлень 3 таргетингової реклами (блок 3) сприяє досягненню маркетингової і комунікаційної ефективності при взаємодії із цільовими аудиторіями.

Чітке i релевантне наповнення маркетингових комунікаційних повідомлень окреслюється завдяки функціонуванню блоку 4. Свропейський вектор розвитку стратегії регіонів у сфері ефективної організації логістичного розподілу потоків товарів і послуг опосередковує накопичення елементів і чинників логістичної інфраструктури, логістичного потенціалу регіонів (блок 5). У методичному блоці 6 генеруються маркетинговотехнологічні складові ефективного застосування нативних рекламних форматів та комунікаційної взаємодії у месенджерах. Під час функціонування маркетингових віртуальних платформ та блогів доцільним $\epsilon$ інформаційне забезпечення динамічного ціноутворення та е-логістики, що визначається у блоці 7 пропонованої процедури (рис. 1). У підсумку в методичній площині блоку 8 відбувається досягнення зрівноваженого маркетингового ланцюга створення потоків додаткової маркетингової вартості у межах концепції зеленої логістики. Водночас має відбуватися збільшення потоків маркетингової цінності у межах регіонального ланцюга поставок.

Проаналізуємо застосування Інтернет-технологій ВТП України протягом 2017-2018 рр. та їх відповідну структуру, таблиця.

Як видно з таблиці найбільшу питому вагу в загальному використанні мережі Інтернет високотехнологічними підприємствами України протягом 2017-2018 рр. посідають такі напрямки, як: надсилання чи отримання повідомлень електронною поштою (питома вага цього напрямку дещо зменшилася $318,55 \%$ у 2017 р. до $18,33 \%$ у 2018 р.), отримання інформації про товари та послуги (16,52\% у структурі в 2017 р. та 16,50\% у 2018 р.). Значущим також є отримання інформації від органів державної влади (15,05\% у 2017 р. та з незначним зниженням до 15,03\% в 2018 р.), здійснення банківських операцій (питома вага цього напрямку у 2017 р. склала 18,22\% і дещо зменшилася до 18,04\% у 2018 р.) [12]. 
Таблиця - Напрями використання мережі Інтернет високотехнологічними підприємствами України та їх структура протягом 2017-2018 pp.

\begin{tabular}{|c|c|c|c|c|c|c|c|}
\hline $\begin{array}{l}\text { № } \\
\text { зП }\end{array}$ & $\begin{array}{l}\text { Показники напрямів } \\
\text { використання мережі } \\
\text { Інтернет } \\
\text { високотехнологічними } \\
\text { підприємствами } \\
\text { України }\end{array}$ & $2017 \mathrm{p}$ & $2018 \mathrm{p}$ & $\begin{array}{l}\text { Струк- } \\
\text { тура } \\
\text { вико- } \\
\text { ристан- } \\
\text { ня, } \\
2017 \text { р., } \\
\%\end{array}$ & $\begin{array}{l}\text { Струк- } \\
\text { тура } \\
\text { вико- } \\
\text { ристан- } \\
\text { ня, } \\
2018 \text { р., } \\
\%\end{array}$ & $\begin{array}{l}\text { Абсолютне } \\
\text { відхилення } \\
\text { за кількістю } \\
\text { підприємств, } \\
\text { одиниць }\end{array}$ & $\begin{array}{l}\text { Відносне } \\
\text { відхилення } \\
\text { за кількістю } \\
\text { підприємств, } \\
\%\end{array}$ \\
\hline 1 & $\begin{array}{l}\text { Кількість } \\
\text { підприємств, які мали } \\
\text { доступ до мережі } \\
\text { Інтернет, одиниць: } \\
3 \text { вихо } \\
\text { використовували } \\
\text { мережу Інтернет для: }\end{array}$ & 39582 & 43303 & & - & 3721 & 9,40 \\
\hline 2 & $\begin{array}{l}\text { Надсилання } \\
\text { отримання } \\
\text { повідомлень } \\
\text { електронною поштою } \\
\end{array}$ & 38929 & 42733 & 18,55 & 18,33 & 3804 & 9,77 \\
\hline 3 & $\begin{array}{l}\text { Здійснення } \\
\text { телефонних дзвінків } \\
\text { за допомогою } \\
\text { Iнтернет/VoIP-зв'язку } \\
\text { або відео-конференцій }\end{array}$ & 12048 & 13673 & 5,74 & 5,86 & 1625 & 13,49 \\
\hline 4 & $\begin{array}{l}\text { Отримання інформації } \\
\text { про товари та послуги }\end{array}$ & 34663 & 38468 & 16,52 & 16,50 & 3805 & 10,98 \\
\hline 5 & $\begin{array}{l}\text { Користування } \\
\text { миттєвим обміном } \\
\text { повідомленнями та } \\
\text { електронною дошкою } \\
\text { oголошень } \\
\end{array}$ & 18704 & 21167 & 8,91 & 9,08 & 2463 & 13,17 \\
\hline 6 & $\begin{array}{l}\text { Отримання інформації } \\
\text { від органів державної } \\
\text { влади }\end{array}$ & 31571 & 35034 & 15,05 & 15,03 & 3463 & 10,97 \\
\hline 7 & $\begin{array}{l}\text { 3дійснення } \\
\text { різноманітних } \\
\text { операцій } 3 \text { органами } \\
\text { державної влади (за } \\
\text { винятком отримання } \\
\text { iнформації) }\end{array}$ & 20158 & 22413 & 9,61 & 9,61 & 2255 & 11,19 \\
\hline 8 & $\begin{array}{l}\text { Здійснення } \\
\text { банківських операцій }\end{array}$ & 38227 & 42070 & 18,22 & 18,04 & 3843 & 10,05 \\
\hline 9 & $\begin{array}{l}\text { Доступ до інших } \\
\text { фінансових послуг }\end{array}$ & 15535 & 17612 & 7,40 & 7,55 & 2077 & 13,37 \\
\hline
\end{tabular}

Джерело: сформовано автором на основі [12] 
Слід відмітити зростання масштабів використання мережі Інтернет високотехнологічними підприємствами України протягом 2017-2018 рр. за усіма означеними напрямками, зокрема на 3721 одиниць збільшилася загальна кількість підприємств, які мали доступ до мережі Інтернет, що у відносному вимірі склало $+9,4 \%$. Розширилися комунікації за телефонними дзвінками за допомогою Інтернет/VoIP-зв'язку або відео-конференцій на 1625 підприємствах, що відносному вираженні склало $+13,49 \%$. Також на 2463 ВТП зросла інтенсивність користування миттєвим обміном повідомленнями та електронною дошкою оголошень $(+13,17 \%)$. На 2077 підприємствах розширився доступ завдяки віртуальним інформаційним технологіям до інших фінансових послуг, що в 2018 р. порівняно з 2017 р. склало $+13,37 \%$ [12].

Виявлені аналітичні тенденції засвідчують комплексне збільшення площини і масштабів використання Інтернет-маркетингових комунікацій за усіма напрямками технологічної бізнес-взаємодії ВТП України. Тому маркетологи i логісти мають системно моніторувати комунікаційну активність підприємств за означеними напрямками, прагнучи підвищити інтенсивність і вартісну наповненість потоків маркетингових цінностей, що спрямовуються до цільових груп споживачів.

Висновки. У роботі уточнено і поглиблено розуміння сутності інтеграційної взаємодії маркетингу і логістики в концепційній системі маркетингового просування інноваційної продукції з урахуванням зелених i віртуальних інформаційних аспектів формування логістичної системи ВТП України. Удосконалено маркетингову ціннісну процедуру поліканального розподілу інноваційної продукції ВТП на основі віртуального забезпечення екологістики. Унаслідок застосування маркетингової ціннісної процедури поліканального розподілу інноваційної продукції ВТП на основі віртуального забезпечення екологістики відбувається досягнення зрівноваженого маркетингового ланцюга створення потоків додаткової маркетингової вартості у межах концепції зеленої логістики. Водночас має відбуватися збільшення потоків маркетингової цінності у межах регіонального ланцюга поставок.

Проведено аналіз комплексного застосування Інтернет-технологій ВТП України та їх відповідну структуру. Встановлено, що найбільшу питому вагу в загальному використанні мережі Інтернет високотехнологічними підприємствами України протягом 2017-2018 рр. посідають такі напрямки, як: надсилання чи отримання повідомлень електронною поштою (питома вага цього напрямку дещо зменшилася $318,55 \%$ у 2017 р. до $18,33 \%$ у 2018 р.), отримання інформації про товари та послуги (16,52\% у структурі в 2017 р. та 16,50\% у 2018 р.). Виявлені аналітичні тенденції засвідчують комплексне збільшення площини i масштабів використання Інтернетмаркетингових комунікацій за усіма напрямками технологічної бізнесвзаємодії ВТП України. Тому маркетологи і логісти мають системно проводити моніторинг комунікаційної активності підприємств за комплексом 
логістично-комунікаційних напрямків. Це сприятиме підвищенню інтенсивності й вартісній наповненості потоків маркетингових цінностей, що спрямовуються до цільових груп споживачів.

Перспективами наукових розробок у досліджуваному напрямі $\epsilon$ розширення науково-методологічного інструментарію інноваційної маркетингової бізнес-взаємодії ринкових агентів у конкурентному просторі каналів маркетингового розподілу. Це має методично супроводжуватися відповідним технологічним проривом у сфері розвитку інноваційних технологій міжнародного цифрового маркетингу.

\section{Література:}

1. Мазаракі А. А. Розвиток логістичної системи України: екологічні виклики / А. А. Мазаракі, Л. Г. Харсун // Економіка України. - 2018. - №9. - С. 3-12.

2. Majchrzak-Lepczyk Justyna, Maryniak Anna. Rynek powierzchni magazynowej i elementy jej wyposażenia. Komitet Redakcyjny: Elżbieta Gołembska, Danuta Krzemińska, Emil Panek, Wiesława Przybylska-Kapuścińska. - Poznań : Wydawnictwo Uniwersytetu Ekonomicznego w Poznaniu, 2016. - 120 s.

3. Kasian Serhii. Determinanty jakościowe zarządzania marketingiem i logistyka dystrybucji przedsiębiorstw: jakość koordynowania potoków zasobów i usług / Serhii Kasian // ARCHIWUM WIEDZY INŻYNIERSKIEJ. POLITECHNIKA CZĘSTOCHOWSKA, KATEDRA INŻYNIERII PRODUKCJI I BIEZPIECZEŃSTWA. - TOM 2. - NR 2 (2017). - S. 3-5. ISSN 2544-2449. ZASÓB ELEKTRONICZNY. - DOSTĘPNIE NA: https://www.qpij.pl/archiwum-wiedzy-inzynierskiej-tom2-nr-2-2017/archiwum3.

4. Зозульов О. В. Формування концепції ведення бізнесу на маркетингових засадах / О. В. Зозульов // Маркетинг в Україні. - 2017. - №5-6. - С. 64-72.

5. Інструменти та методи комерціалізації інноваційної продукції : монографія / за ред. д.е.н., проф. Ілляшенка С. М., к.е.н., доц. Біловодської О. А. - Суми : Триторія, 2018. 382 http://er.chdtu.edu.ua/bitstream/ChSTU/109/1/Моно_Ілляшенко_Біловодська_НОВ\%20\%2 82\%29.PDF.

6. Касян С. Я. Маркетингове забезпечення ефективного просування інноваційних електротехнічних розробок високотехнологічних підприємств / С.Я.Касян, А. Г. Барсуков // Економічний простір: Збірник наукових праць. - Дніпро: Придніпровська державна академія будівництва та архітектури. - 2017. - №126. C. $178-191 \quad$ (216 c.) INDEX http://journals.indexcopernicus.com/+,p3843,3.html. GOOGLE COPERNICUS: https://scholar.google.com.ua/citations?user=sLRr06MAAAAJ\&hl=ru. ISSN 2224-6282. ISSNe 2224-6290.

7. Лебеденко С. О. Застосування маркетингових Інтернет інструментів на прикладі державного підприємства «Антонов» / С. О. Лебеденко, Н. К. Мороз // Ефективна економіка. - 2018. - №11. - [Електронний ресурс]. - Режим доступу : http://www.economy.nayka.com.ua/?op=1\&z=6659 (дата звернення: 12.02.2019). DOI: $10.32702 / 2307-2105-2018.11 .56$ http://www.economy.nayka.com.ua/pdf/11_2018/58.pdf.

8. International Centre for East European Research / Międzynarodowe Centrum Badań Wschodnioeuropejskich ) Лодзьського університету (University of Lodz) [Wydział Studiów Międzynarodowych i Politologicznych, Uniwersytet Łódzki. Struktura i Pracownicy. $\begin{array}{llllll}\text { Jednostki. } \quad-\quad \text { [Zasób } & \text { elektroniczny]. } & - & \text { Dostęp, } & 02.03 .2019\end{array}$ http://www.wsmip.uni.lodz.pl/wydzial/artykuly/jednostki-65.html. 
9. Домашева Є. А. Визначення стратегії збуту в кіберсередовищі на промисловому ринку / Є. А. Домашева, О. В. Зозульов // Економічний вісник НТУУ «КПІ». - 2018. - №15. C. 299-307.

10. Голованова Майа. Динамічне ціноутворення як інструмент задоволення потреб вузьких сегментів ринку / Майа Голованова // Маркетинг в Україні. - 2016. - №6 (99). С. $18-19$.

11. Економіка логістичних систем : монографія / М. Васелевський, І. Білик, О. Дейнега та ін. ; за наук. ред. Є. Крикавського, С. Кубіва. - Львів : вид-во Націон. унів-ту «Львівська політехніка», 2008. - 596 с.

12. Офіційний сайт Державної служби статистики України. Статистична інформація. Використання інформаційно-комунікаційних технологій на підприємствах. [Електронний ресурс]. - Режим доступу, 18.04.2019 : http://www.ukrstat.gov.ua. 